\title{
Effect of Botanicals on Drechslera oryzae and Meloidogyne graminicola of Rice (Oryza sativa L.)
}

\author{
R.V. Neeraja Reddy*, P. Niveditha, Sobita Simon and Abhilasha A. Lal \\ Department of Plant Pathology, Sam Higginbottom University of Agriculture, \\ Technology and Sciences, India \\ *Corresponding author
}

\section{A B S T R A C T}

\begin{tabular}{l} 
Ke y w o r d s \\
$\begin{array}{l}\text { Drechslera oryzae, } \\
\text { Meloidogyne } \\
\text { graminicola, } \\
\text { Botanical extracts, } \\
\text { Poisoned food } \\
\text { Technique }\end{array}$ \\
\hline Article Info \\
\hline $\begin{array}{l}\text { Accepted: } \\
\text { 04 September } 2019 \\
\text { Available Online: } \\
\text { 10 October } 2019\end{array}$ \\
\hline
\end{tabular}

Brown spot of rice caused by Drechslera oryzae and rice root-knot nematode caused by Meloidogyne graminicola are serious pest of rice and has become a major constraint in rice production throughout the world. A lab experiment was conducted in Laboratory of the Department of Plant Pathology, SHUATS, Prayagraj, and U.P. during 2018-19 to observed the effect of botanicals viz., against Drechslera oryzae and Meloidogyne graminicola of rice. In vitro the selected botanicals Neem, Ashoka, Moringa, Aloe vera, Hibiscus, Curry leaves and Lantana leaf extracts $10 \%$ against Drechslera oryzae were tested in food poisoned technique to see the effectiveness. Radial growth $(\mathrm{mm})$ was recorded at 24,48 and $72 \mathrm{hrs}$ after exposure in the treatments. Among the treatments of botanicals Neem leaf extract shows significant reduce in radial growth of Drechslera oryzae at $24 \mathrm{hrs}$ (7.93), 48 hrs (14.57), and $72 \mathrm{hrs}(23.23)$ as compared with control $(18.80,29.20,40.73)$. In the pot experiment infected rhizospheric soil of 2000 larvae/pot (500 gm soil) were filled in plastic pots and selected botanical leaf extracts incorporate the $100 \mathrm{gm}$ of leaves in $100 \mathrm{ml}$ of water (w/v) extracts were superintend in each treatment of four replications for the control of root-knot population of Meloidogyne graminicola of rice. Nematode populations of plants were recorded at 40 days after exposure of the treatments. Among the treatments root-knot population (Meloidogyne graminicola) Aloe vera (7) and Ashoka (7) shows significantly reduced of Meloidogyne graminicola population as compared to control (24). Based on the findings it was concluded that Neem leaf extract was proved to be most effective against Drechslera oryzae and Aloe vera, Ashoka were proved to be most effective against the root-knot population of Meloidogyne graminicola.

\section{Introduction}

Phytochemicals are chemical compounds that occur naturally in the plant kingdom. Some are responsible for the organoleptic properties of the natural sources in which they are present. Physiologically active plant constituents are usually classified by their chemical structure rather than specific actions and include Alkaloids, Anthocyanins, Anthraquinones, Cardiac Glycosides, Coumarins, Cyanogenic Glycosides, Flavonoids, Glucosilinates, Phenols, Saponins and Tannins. Plant derived products can be 
exploited with a large number of sustainable advantages like more effectiveness, less side effects, reduced cost, easy availability (Moorthy et al., 2007).

Brown spot of rice caused by Drechslera oryzae (Breda de Haan). Is one of the major fungal diseases of rice which occurs in almost all the rice grown areas. It is one of the important soil and seed borne disease, which cause substantial quantitative and qualitative grain losses in grain yield. The disease is more prevalent where water supply is scarce combined with nutritional imbalance particularly nitrogen, silicon during abiotic conditions (Baranwal et al., 2013). The fungus was originally reported from the rice leaves causing brown spot disease.

Meloidogyne graminicola is a serious pest of rice and has become a major constraint in rice production throughout the world. Meloidogyne graminicola are in the form of terminal hook shaped or spiral galls (Khan et al., 2012). There are various methods available for the management of rice root-knot nematode including fallowing, flooding, deep ploughing, biological control and nematicidal application. Despite concern about the use of chemical pesticides throughout the world, due to adverse effects on the ecosystem (Haq et al., 1990), chemical pesticides are still the most effective means of management of nematodes in the rice ecosystem (Prasad et al., 2010).

\section{Materials and Methods}

\section{Isolation of the pathogen (Drechslera oryzae)}

Small pieces of tissues about $3 \mathrm{~mm}$ from infected collar region with some healthy tissue where cut with sterile scalpel. Then the pieces surface sterilized with one percent sodium hypochlorite solution for $30 \mathrm{sec}$. The tissue pieces were subsequently washed in three changes of sterile distilled water to eliminate excess sodium hypochlorite and then pieces were transferred to PDA plated petri dishes. Plates were incubated at $28 \pm 2^{\circ} \mathrm{C}$ and were observed periodically for growth of the fungus.

\section{Characters of Drechslera oryzae}

The fungus grows on potato dextrose agar at $250^{\circ} \mathrm{C}$ and appears as delicate, black and grey fluffy growth. The somatic structures of the fungus consist of black velvety mycelial mats which are made up of prostrate hyphae and erect sporophores. The hyphae are abundant, branching, and anatomizing. They are dark brown or olivaceous and measure 8-15 $\mu \mathrm{m}$ or more in diameter. The sporophores arise as lateral branches from the hyphae. The conidia measure 35-170 $\times 11-17 \mu \mathrm{m}$ typical conidia were slightly curved, fusoid, or obclavate, occasionally almost cylindrical, pale to mid golden brown, 5 to 6 septate with hilum. Mature conidia are brownish with a moderately thin peripheral wall (Subram and Jain 1966).

\section{Poisoned food technique}

Five $\mathrm{mm}$ diameter of culture disc of Drechslera oryzae was taken with the help of cork borer and was kept at the centre of each petriplate containing botanical extracts of required concentration dissolved in PDA. Three replications were maintained.

The plates were incubated at $27^{\circ} \mathrm{C}$ for ten days and colony diameter was recorded. Percent inhibition of mycelial growth was calculated by using the formula given by Vincent (1947).

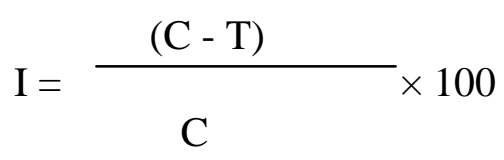


$\mathrm{C}=$ Mycelium weight in control.

$\mathrm{T}=$ Mycelium weight in treatment.

\section{Characteristics of Meloidogyne graminicola}

Meloidogyne graminicola are in the form of terminal hook shaped or spiral galls. Juveniles enter the roots through root tips and start feeding. Symptoms are characterized by abnormal swelling on roots known as rootknots or galls, yellowing, stunting and wilting of the plants. Meloidogyne graminicola, when plants are in their first stages of vegetative development (early summer), patches of plants showing poor growth, loss of vigour, stunting, chlorosis with heavily affected root systems can be observed. In late summer and autumn, the above-ground symptoms may regress after flooding and fertilizing, as patches are colonised by the vegetation of growing and tillering plants (Golden and Birchfield, 1968).

\section{Results and Discussion}

The results of $24 \mathrm{hrs}$ indicate that among the treatments $\mathrm{T}_{1}$ (Neem-7.93), $\mathrm{T}_{7}$ (Ashoka-9.37), $\mathrm{T}_{6}$ (Aloe vera - 10.50), $\mathrm{T}_{5}$ (Moringa - 11.43) and $\mathrm{T}_{2}$ (Lantana - 13.60) $\mathrm{T}_{4}$ (Curry leaves16.47), $T_{3}$ (Hibiscus - 17.37) and $T_{0}$ (Control 18.80) were significantly differ the radial growth of Drechslera oryzae from each other.

The results showed that $\mathrm{T}_{1}$ (Neem - 57.80\%) shows the maximum mycelial growth inhibition percentage followed by $\mathrm{T}_{7}$ (Ashoka - 50.18\%), $\mathrm{T}_{6}$ (Aloe vera - 4.15\%), $\mathrm{T}_{5}$ (Moringa -39.18\%), $\mathrm{T}_{2}$ (Lantana - 27.66\%), $\mathrm{T}_{4}$ (Curry leaves - $12.41 \%$ ), $\mathrm{T}_{3}$ (Hibiscus $7.62 \%)$.

The results of $48 \mathrm{hrs}$ indicate that the treatments $\mathrm{T}_{6}$ (Aloe vera - 17.23), $\mathrm{T}_{5}$ (Moringa-18.27), $\mathrm{T}_{2}$ (Lantana - 22.43), $\mathrm{T}_{4}$ (Curry leaves - 26.63) and $\mathrm{T}_{3}$ (Hibiscus 28.23) are significantly reduced the radial growth of Drechslera oryzae as compared to $\mathrm{T}_{1}$ (Neem - 14.57), $\mathrm{T}_{7}$ (Ashoka - 15.23) and $\mathrm{T}_{0}$ (Control - 29.20).

Whereas $T_{4}$ and $T_{3}$ over non-significant from each other but significantly reduced from $\mathrm{T}_{0}$.

The results showed that $\mathrm{T}_{1}$ (Neem - 50.11\%) shows the maximum mycelial growth inhibition percentage followed by $\mathrm{T}_{7}$ (Ashoka - 47.83\%), $\mathrm{T}_{6}$ (Aloe vera - 40.98\%), $\mathrm{T}_{5}$ (Moringa-37.44\%), $\mathrm{T}_{2}$ (Lantana - 23.17\%), $\mathrm{T}_{4}$ (Curry leaves $-8.79 \%$ ), $\mathrm{T}_{3}$ (Hibiscus $-3.31 \%$ ).

The same treatments series were found in 72 hrs after incubation again. The results of $72 \mathrm{hrs}$ indicate that all the treatments $\mathrm{T}_{1}$ (Neem 23.23), $\mathrm{T}_{7}$ (Ashoka - 25.47), $\mathrm{T}_{6}$ (Aloe vera28.93), $\mathrm{T}_{5}$ (Moringa - 31.40), $\mathrm{T}_{2}$ (Lantana 33.13), $\mathrm{T}_{4}$ (Curry leaves - 36.30) and $\mathrm{T}_{3}$ (Hibiscus-37.37) are significantly reduced the radial growth of Drechslera oryzae as compared to $\mathrm{T}_{0}$ (Control - 40.73).

Maximum mycelial growth inhibition percentage was found in $\mathrm{T}_{1}$ (Neem - 42.96\%) followed by $\mathrm{T}_{7}$ (Ashoka $-37.48 \%$ ), $\mathrm{T}_{6}$ (Aloe vera $-28.93 \%), \mathrm{T}_{5}$ (Moringa - 22.91\%), $\mathrm{T}_{2}$ (Lantana - 18.66\%), $\mathrm{T}_{4}$ (Curry leaves 10.88\%), $\mathrm{T}_{3}$ (Hibiscus - 8.27\%).

The results of 40 days indicate that the population of Meloidogyne graminicola was found in $\mathrm{T}_{1}$ (Ashoka - 7) and $\mathrm{T}_{5}$ (Aloe vera - 7) which are significantly reduced the root gall population as compared to $\mathrm{T}_{3}$ (Neem-11), $\mathrm{T}_{4}$ (Lantana - 12), $\mathrm{T}_{2}$ (Moringa - 15) and $\mathrm{T}_{0}$ (Control - 24). Whereas $T_{1}$ and $T_{5}$ shown nonsignificant from each other being in the order $\mathrm{T}_{1} \leq \mathrm{T}_{5} \leq \mathrm{T}_{3} \leq \mathrm{T}_{4} \leq \mathrm{T}_{2} \leq \mathrm{T}_{0}$.

Maximum percentage of reduction over control was obtained is $T_{1}$ - Ashoka (70.83) and $\mathrm{T}_{5}-$ Aloe vera (70.83) followed by $\mathrm{T}_{3}$ Neem (54.12), $\mathrm{T}_{4}$ - Lantana (50) and $\mathrm{T}_{2}$ Moringa (37.50). 
Table.1 In-vitro evaluation of plant extracts on the radial growth $(\mathrm{mm})$ of Drechslera oryzae at different period's interval

\begin{tabular}{|c|c|c|c|c|c|c|c|}
\hline \multirow[t]{2}{*}{ S.NO. } & \multirow[t]{2}{*}{ TREATMENTS } & \multicolumn{6}{|c|}{ Radial growth $(\mathrm{mm})$ of the three replicants mean } \\
\hline & & 24hrs & $\begin{array}{c}\text { Inhibition } \\
\%\end{array}$ & $48 \mathrm{hrs}$ & $\begin{array}{c}\text { Inhibition } \\
\%\end{array}$ & 72hrs & $\begin{array}{c}\text { Inhibition } \\
\%\end{array}$ \\
\hline $\mathbf{T}_{\mathbf{0}}$ & Control & 18.80 & - & 29.20 & - & 40.73 & - \\
\hline $\mathbf{T}_{1}$ & Neem & 7.93 & 57.80 & 14.57 & 50.11 & 23.23 & 42.96 \\
\hline $\mathbf{T}_{2}$ & Lantana & 13.60 & 27.66 & 22.43 & 23.17 & 33.13 & 18.66 \\
\hline $\mathbf{T}_{3}$ & Hibiscus & 17.37 & 7.62 & 28.23 & 3.31 & 37.37 & 8.27 \\
\hline $\mathbf{T}_{4}$ & Curry leaves & 16.47 & 12.41 & 26.63 & 8.79 & 36.30 & 10.88 \\
\hline $\mathbf{T}_{5}$ & Moringa & 11.43 & 39.18 & 18.27 & 37.44 & 31.40 & 22.91 \\
\hline $\mathbf{T}_{6}$ & Aloe vera & 10.50 & 44.15 & 17.23 & 40.98 & 28.93 & 28.93 \\
\hline $\mathbf{T}_{7}$ & Ashoka & 9.37 & 50.18 & 15.23 & 47.83 & 25.47 & 37.48 \\
\hline \multicolumn{2}{|c|}{ S. Ed. ( \pm$)$} & \multicolumn{2}{|c|}{0.296} & \multicolumn{2}{|c|}{0.716} & \multicolumn{2}{|c|}{0.714} \\
\hline \multicolumn{2}{|c|}{ CD $(5 \%)$} & \multicolumn{2}{|c|}{0.63} & \multicolumn{2}{|c|}{1.52} & \multicolumn{2}{|c|}{1.51} \\
\hline
\end{tabular}

Table.2 Nematode population of rice plants as affected by treatments

\begin{tabular}{|c|c|c|c|}
\hline \multirow[t]{2}{*}{ S.NO. } & \multirow[t]{2}{*}{ Treatments } & \multicolumn{2}{|c|}{$\begin{array}{c}\text { Meloidogyne graminicola } \\
\text { population at } 90 \text { days after } \\
\text { germination of rice }\end{array}$} \\
\hline & & $\begin{array}{l}\text { Mean of the three } \\
\text { replicants }\end{array}$ & $\begin{array}{l}\% \text { reduction } \\
\text { over control }\end{array}$ \\
\hline $\mathbf{T}_{\mathbf{0}}$ & Control (Nematode) & 24 & 100 \\
\hline $\mathbf{T}_{1}$ & Ashoka + Nematodes & 7 & 70.83 \\
\hline $\mathbf{T}_{2}$ & Moringa + Nematodes & 15 & 37.50 \\
\hline $\mathbf{T}_{\mathbf{3}}$ & Neem + Nematodes & 11 & 54.12 \\
\hline $\mathbf{T}_{4}$ & Lantana + Nematodes & 12 & 50 \\
\hline $\mathbf{T}_{5}$ & Aloe vera + Nematodes & 7 & 70.83 \\
\hline & Ed. $( \pm)$ & \multicolumn{2}{|c|}{2.52} \\
\hline & $\mathrm{D}(5 \%)$ & \multicolumn{2}{|c|}{5.35} \\
\hline
\end{tabular}


The present studies clearly indicate that Botanicals were found effective compared with other treatments against Drechslera oryzae and Meloidogyne graminicola (Neem, Ashoka and Aloe vera) recorded maximum inhibition growth and root galls population. The botanicals produce secondary metabolites such as alkaloids, flavonoids, steroids, resins, fatty acids, tannins and phenol compounds. They are effective in the treatment of infectious diseases while simultaneously minimizing many of the side effects that are often associated with synthetic antimicrobials. These botanicals reduced the disease severity of Drechslera oryzae (brown spot) and Meloidogyne graminicola (root-knot) populations of rice. Thus these eco friendly treatments found as an interesting alternative to fungicides due to their less negative impacts on the environment and easy availability as well as they are economically feasible.

\section{References}

Barnwal, M. K., Kotasthane, A., Magculia, N., Mukherjee, P. K., Savary, S., Sharma, A. K., Singh, U. S., Sparks, A. H., Variar, M. and Zaidi, N. (2013). A review on crop losses, epidemiology and disease management of rice brown spot to identify research priorities and knowledge gaps. European Journal of Plant Pathology. 39(2): 365-366.

Golden, A. M. and Birchfield W. (1968). Rice root knot nematode (Meloidogyne graminicola) as a new pest of rice. Plant Disease Reporter. 52: 423.

Haq, S., Sexena S. and Khan, M. W. (1990). Chemical control of plant nematodes in relation to environment pollution. In: Progress in Nematology (S.K Saxena, M.W. Khan, A. Rashid, R.M. Khan, ed.). CBS Publishers and distributors, Delhi, India. Pp. 297-320.

Haq, S., Sexena S. and Khan, M. W. (1990). Chemical control of plant nematodes in relation to environment pollution. In: Progress in Nematology (S.K Saxena, M.W. Khan, A. Rashid, R.M. Khan, ed.). CBS Publishers and distributors, Delhi, India. 297-320.

Khan, M. R., Zaidi, B. and Haque, Z. (2012). Nematicides control rice root-knot, caused by Meloidogyne graminicola. Phytopathology Meditterranean. 51: 298-06.

Moorthy, K., Srinivasan, K., Subramanian, C., Mohanasundari, C. and Palaniswamy, M. (2007). Phytochemical screening and antibacterial evaluation of stem bark of Mallotus philippinensis var. tomentosus. African Journal of Biotechnology. 6: 1521-1523.

Prasad, J. S., Somasekhar, N. and Varaprasad, K. S. (2010). Nematode infestation in Paddy In: Nematode Infestations, Part I: Food Crop (M.R. Khan, M.S. Jairajpuri, ed.). National Academy of Sciences, India. Pp. 17-71.

Subramanian, C. V., Jain, B. L. (1966). A revision of some graminicolous Helminthospora. Current Science. 35(14): 352-355.

Vincent, J. M. (1947). Distortion of fungal hyphae in presence of certain inhibitors. Nature. 150: 850.

\section{How to cite this article:}

Neeraja Reddy, R.V., P. Niveditha, Sobita Simon and Abhilasha A. Lal 2019. Effect of Botanicals on Drechslera Oryzae and Meloidogyne graminicola of Rice (Oryza sativa L.). Int.J.Curr.Microbiol.App.Sci. 8(10): 388-392. doi: https://doi.org/10.20546/ijcmas.2019.810.040 